\title{
Diet-Derived Halogenated Metabolite from the Sea Hare Aplysia parvula
}

\author{
Charles S. Vairappan ${ }^{1}$, Sangeetha P. Anangdan ${ }^{1}$ and Shigeki Matsunaga ${ }^{2}$
}

${ }^{1}$ Laboratory of Natural Products Chemistry, Institute for Tropical Biology and Conservation, Universiti Malaysia Sabah, 88999 Kota Kinabalu, Sabah, Malaysia.

${ }^{2}$ Laboratory of Aquatic Natural Products Chemistry, Graduate School of Agriculture and Life Sciences, Faculty of Agriculture, The University of Tokyo, Bunkyo-ku, Tokyo, Japan. *csv@ums.edu.my(corresponding author )

Received on $22^{\text {nd }}$ Febuary 2009, accepted in revised form $6^{\text {th }}$ November 2009.

\begin{abstract}
As part of our continuous interest in the diversity of halogenated metabolites in the red algae genus Laurencia and their grazers, the sea hare genus Aplysia in Sabah coastal waters, we report the chemical composition of Aplysia parvula collected from Sepanggar Island, Kota Kinabalu. Chemical analysis resulted in the isolation and identification of three sesquiterpenes; palisadin A (1), iso-obtusol (2) and elatol (3). Compounds were present as $13.9 \%, 6.7 \%$, and $8.5 \%$ of crude extract, respectively. A similar analysis of its diet from the same location, Laurencia snackeyi (Weber-van Bosse) Masuda and Laurencia majuscula (Harvey) Lucas, showed the existence of palisadin A, palisadin B, aplysistatin and 5-acetoxypalisadin B in Laurencia snackeyi, while Laurencia majuscula contained elatol and isoobtusol. Hence, it is suggestive that $A$. parvula is capable of selective sequestering of compounds derived from its diet. Based on the chemicals sequestered, it is confirmed that A. parvula is an oligophagous feeder. Its ability to selectively sequester palisadin A and not the other syndreans, reflects on the complexity of its digestive glands. All three compounds also showed potent antimicrobial, antifeedant and cytotoxic activities.
\end{abstract}

ABSTRAK Sehubungan dengan minat kami dalam penyelidikan sebatian berhalogen 'seahare' dari perairan Sabah, kami ingin melaporkan komposisi kimia sebatian berhalogen dari Aplysia parvula dari Pulau Sepanggar, Kota Kinabalu. Hasil kajian telah membawa kepada pemencilan dan identifikasi tiga sesquiterpene; Palisadin A (1), iso-obtusol (2) and elatol (3). Sebatian-sebatian ini wujud dalam kuantiti yang signifikan 13.9\%, 6.7\%, and 8.5\% dalam esktrak kasarnya 'sea hare' yang dikaji. Analisis kimia sedemikian keatas dietnya, Laurencia snackeyi (Weber-van Bosse) Masuda and Laurencia majuscula (Harvey) Lucas, telah menunjukkan kehadiran palisadin A, palisadin B, aplysistatin and 5-acetoxypalisadin B dalam Laurencia snackeyi, manakala Laurencia majuscula mengandungi elatol and isoobtusol. Maka, dapat disyorkan bahawa A. parvula dapat melakukan menepuan sebatian kimia daripada dietnya secara selektif. Berdasarkan bahan kimia yang ditepukan, dapat dikenalpasti bahawa $A$. parvula merupakan pemakan oligofagus. Kebolehannya untuk melakukan penemuan selektif terhadap palisadin A dan bukan 'syndrean' yang lain dapat membayangkan betapa kompleksnya kelenjar penghadamannya. Semua ketiga-tiga sebatian ini telah menunjukkan aktiviti antimikrob, 'antifeedant' dan sititoksik.

(Keywords: Aplysia parvula, Laurencia majuscula, Laurencia snackeyi, chemical ecology, halogenated metabolite.)

\section{INTRODUCTION}

Sea hares (Opisthobranchia: Anaspidea) are herbivorous gastropods with a soft body which feed predominantly on marine algae and can be found abundantly throughout the tropical/subtropical seas [1]. They generally consume seaweeds that are chemically rich in secondary metabolites and concentrate these metabolites in their digestive glands [2]. Sea hares from the genus Aplysia are known to feed on red algae including Laurencia that are known to be prolific producers of halogenated secondary metabolites [3, 4, and 5]. Seaweed-derived halogenated metabolites are either accumulated as they are, selectively sequestered or subjected to chemical modifications in their digestive system [6].
As a result sea hares accumulate a variety of metabolites and some are known to exhibit various types of biological activities [7, 8, 9, and 10]. Based on the existing reports, sequestered secondary metabolites are suggested to act as defensive chemicals for sea hares [11]. The ability of their digestive glands to facilitate chemical modifications makes these gastropods an attractive research subject for natural products chemists [5].

Hitherto, very few findings on the chemistry and the interrelationship between Laurencia and sea hares from Malaysian waters have been published. In our previous work, we reported the isolation of five sesquiterpenes from Aplysia dactylomela Rang collected from the Western and Northern coast of 
Sabah [11]. Hence, as part of our continuous effort to study the chemical ecology of sea hares we report herein the halogenated metabolites of Aplysia parvula Guilding Morch from the Western coast of Sabah waters.

\section{MATERIALS AND METHODS}

\section{Sample Collection}

Specimens of $A$. parvula were collected in May 2007 from seaweed beds from the waters of Sepanggar Island, Kota Kinabalu, Sabah, Malaysia. (0603'350'N , 116 ${ }^{\circ} 04^{\prime} 140$ 'E). Latitude and longitude were recorded using GPS 12XL (GARMIN Olathe, KS, USA).

\section{Chemical Analysis}

Sea hares were starved for 24 hours prior to extraction; this was done to avoid isolation of compounds from algal residues (diet) in their digestive tract. Digestive tract of four specimens of A. parvula weighing at $25 \mathrm{~g}$ in total was extracted in $\mathrm{MeOH}$ for three days. The $\mathrm{MeOH}$ extract was concentrated in vacuo and partitioned twice between $\mathrm{Et}_{2} \mathrm{O}$ and distilled $\mathrm{H}_{2} \mathrm{O}$. The resulting $\mathrm{Et}_{2} \mathrm{O}$ fraction was dried over $\mathrm{Na}_{2} \mathrm{SO}_{4}$ anhydrous and concentrated in vacuo to yield $28 \mathrm{mg}$ of crude extract. Chemical profiling and isolation of the halogenated metabolites were performed on a High Performance Liquid Chromatography (HPLC) system consisting of a Shimadzu SLC-10A Controller, SPD-20A UV-Vis Detector, and a Ross plotter. Chromatography analysis was performed on a 10 x $250 \mathrm{~mm}$ Phenomenex Luna Phenyl Hexyl reversed phase column with acetonitrile-water (70:30, v/v) as mobile phase. The HPLC operating parameters were as follows: injection volume, $5 \mathrm{~mL}$ (Analytical) and 100 $\mathrm{mL}$ (Semi-preparative); column flow rate, 2.0 $\mathrm{mL} / \mathrm{min}$; chromatographic run time, $50 \mathrm{~min}$; UV spectra recording, $220 \mathrm{~nm}$. The three compounds were present as major peaks in HPLC profile and it corresponded to $\mathrm{SiO}_{2} \quad \mathrm{~F}_{254 \mathrm{~nm}}$ Thin Layer Chromatography developed in hexane: EtOAc (3:1), sprayed with 5\% molybdophosphoric acid in ethanol. Compound identification was carried out based on spectroscopic data.

\section{Spectroscopic Procedure}

Spectroscopy data were measured using ${ }^{1} \mathrm{H}-\mathrm{NMR}$ $(600 \mathrm{MHz})$ and ${ }^{13} \mathrm{C}-\mathrm{NMR}(150 \mathrm{MHz})$, JEOL ECA $600 \mathrm{MHz}$; CDCl; with TMS as internal standard. The melting point was measured on a micro-melting point apparatus (Fisher Scientific) and was uncorrected. Optical rotations were measured on a JASCO DIP140 polarimeter and LR/HREIMS, on a JEOL JMSA500 spectrometer.

\section{Bioassay}

Cytotoxic P388 murine leukemia cells (JCRB 17) were cultured in RPMI 1640 medium (Nissui Pharm. Co., Tokyo) supplemented with $100 \mu \mathrm{g} / \mathrm{mL}$ of kanamycin (Nacalai Tesque Inc., Kyoto), $10 \%$ of fetal bovine serum (Hyclone Laboratories, Inc., Logan, UT), and $10 \mu \mathrm{M} / \mathrm{mL}$ of 2-hydroxyethyl disulfide (Nacalai Tesque Inc. Kyoto) at $37^{\circ} \mathrm{C}$ under an atmosphere of $5 \% \mathrm{CO}_{2}$. To each well of 96-well microplate which contained $100 \mu \mathrm{L}$ of tumor cell suspension of $1 \times 10^{4}$ cells/mL, $100 \mu \mathrm{L}$ of test solution (sample dissolved in RPMI 1640 medium) was added and the plates were incubated for $96 \mathrm{~h}$. After addition of $50 \mathrm{~mL}$ of 3-(4, 5-dimethyl-2-thiazolyl)-2, 5diphenyl-2H tetrazolium bromide (MTT) saline solution $(1 \mathrm{mg} / \mathrm{mL})$ to each well the plates were incubated for $3 \mathrm{~h}$ under the same conditions. The mixtures were centrifuged and the supernatants were removed. The precipitates obtained were dissolved in DMSO, and absorbance at $550 \mathrm{~nm}$ was measured with a dual wavelength flying spot scanning densitometer.

\section{RESULTS AND DISCUSSION}

Chemical profiling of the extract was performed via reversed phase HPLC as described in the earlier section. Figure 1 shows the presence of three major peaks at $13.50 \mathrm{~min}, 16.20 \mathrm{~min}$, and $16.65 \mathrm{~min}$. All three peaks were collected and spotted on $\mathrm{SiO}_{2}$ gel Thin Layer Chromaotography, developed in toluene and hexane: EtOAc (3:1) solvent systems, visualized by UV light $(254 \mathrm{~nm})$ and molybdophosphoric acid. Upon repeated purification steps, these compounds were isolated in pure form and subjected to spectroscopic data measurements. Physical properties and detailed ${ }^{1} \mathrm{H}-\mathrm{NMR},{ }^{13} \mathrm{C}-\mathrm{NMR}$ and 2D-NMR data lead to the identification of these three compounds (Figure 2) and these are given below:

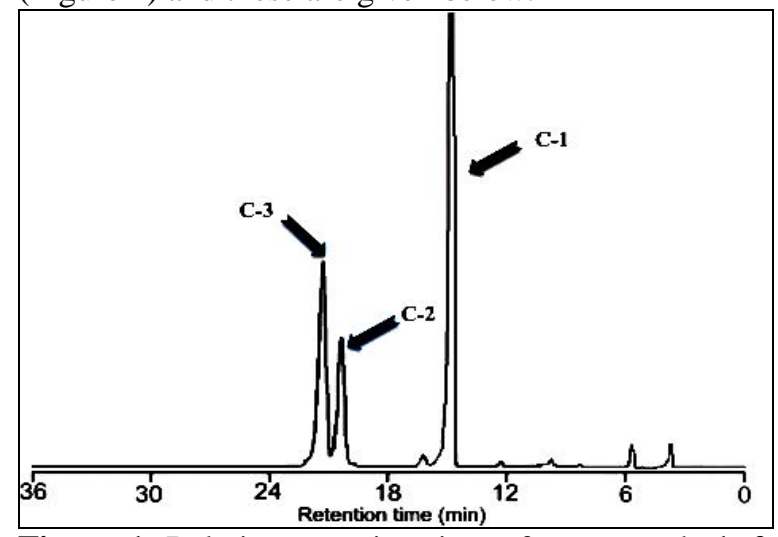

Figure 1. Relative retention time of compounds 1, 2 and $\mathbf{3}$ in their crude methanol extract of Aplysia parvula (C-1: $13.50 \mathrm{~min}, \mathrm{C}-2$ : $16.20 \mathrm{~min}$, and C-3: $16.65 \mathrm{~min})$. 

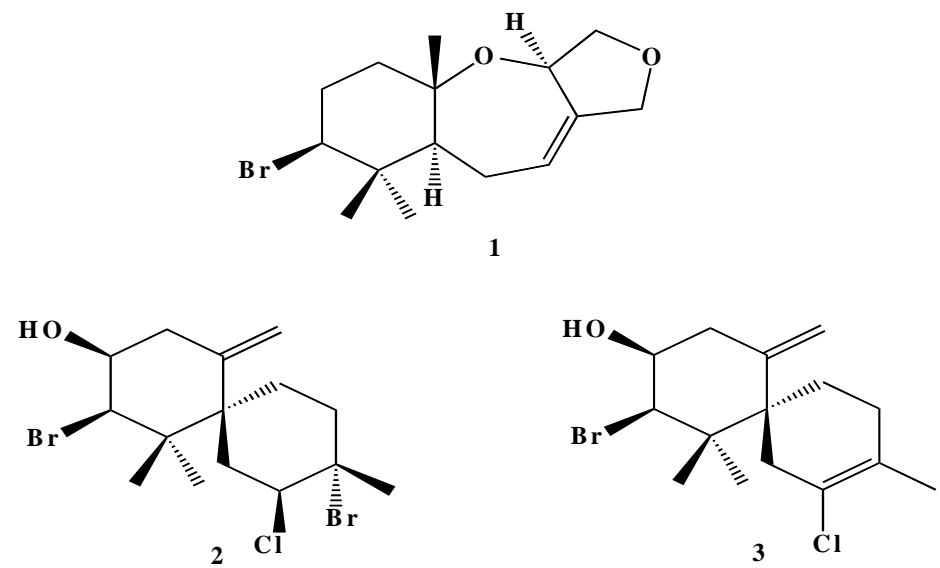

Figure 2. Chemical structure of palisadin A (1), elatol (2), and iso-obtusol (3) isolated from crude methanol extract of Aplysia parvula.

Compound 1 - oil, $[\alpha]^{24}+19.0^{\circ}\left(c 0.16, \mathrm{CHCl}_{3}\right)$; ${ }^{1} \mathrm{H}-\mathrm{NMR}$ and ${ }^{13} \mathrm{C}-\mathrm{NMR}$ are as reported by Vairappan et al. (2007) [10] and Paul and Fenical (1980) [12]. Compound 1 was identified as palisadin $\mathrm{A}$ and was present as $13.9 \%$ of its crude extract.

Compound 2 - solid, $[\alpha]^{24}+24.6^{\circ}\left(c 0.50, \mathrm{CHCl}_{3}\right)$; ${ }^{1} \mathrm{H}-\mathrm{NMR}$ and ${ }^{13} \mathrm{C}-\mathrm{NMR}$ are as reported by Wessels et al. (2000) and Vairappan (2003) [8,10]. Compound was identified as iso-obtusol and was present as $6.7 \%$ of its crude extract.

Compound 3 - oil, $[\alpha]^{24}{ }_{\mathrm{D}}+75.3^{\circ}\left(c\right.$ 0.40, $\left.\mathrm{CHCl}_{3}\right)$; ${ }^{1} \mathrm{H}-\mathrm{NMR}$ and ${ }^{13} \mathrm{C}-\mathrm{NMR}$ are as reported by Wessels et al (2000) and Vairappan (2003) [8,10]. Compound 3 was identified as elatol and was present as $8.5 \%$ of its crude extract.

Similar chemical analysis carried out on its natural seaweed diet such as Laurencia snackeyi and $L$. majuscula revealed that palisadin A was found in Laurencia snackeyi (Weber-van Bosse) Masuda, together with palisadin B, aplystatin and 5acetoxypalisadin B (Figure 3 ). In $L$. snackeyi, aplystatin was present as major metabolite followed by 5-acetoxypalisadin B, palisadin A and palisadin B, as $14.6 \%, 8.5 \%, 6.2 \%$ and $5.1 \%$ of its crude seaweed extract, respectively [11]. While elatol and isoobtusol were found in Laurencia majuscula (Harvey) Lucas that was found growing in the same location from where the sea hares were collected (Figure 4). In L. majuscula, isoobtusol and elatol were present as $8.6 \%$ and $6.4 \%$ respectively. During our field investigation, A. parvula was seen attached to the thalli of these seaweeds. This is the first reported sighting and isolation of metabolites from A. parvula from Malaysian waters. Chemical analysis of $A$. parvula from other regions such as Japan and
Australian showed the presence of diet derived metabolites such as costatone, isolaurenisol acetate and allolaurinterol acetate, but these compounds were not detected in the HPLC analysis of our specimens (Figure 5) [1,9,13].

In our previous investigation, we reported Aplysia dactylomela that feeds only on $L$. snackeyi although there were other Laurencia species growing in the vicinity [11]. Therefore it was establish that Aplysia dactylomela is a specialist feeder. On the contrary, $A$. parvula seems to be feeding on both Laurencia species based on field observation and chemical analysis. This indicates that it is an oligophagous feeder and it corresponds with other studies on $A$. parvula carried out in Japan and Australia $[1,13]$. It is believed that the sea hare sequesters and harbors these metabolites in its digestive tract to be utilized as defense mechanism [3, 14, and 15]. The presence of only palisadin A derived from L.snackeyi, as compared to A. dactylomela that contained the other three metabolites and few modified ones is another interesting observation. Selective retention of palisadin A in such a high concentration should have a meaning, perhaps as an important defense compound for this organism. In nature, palisadin A is an unstable compound and could easily be converted to aplysistatin. Hence, its ability to exist as a sole syndrean metabolite in A. parvula reflects on the unique $\mathrm{pH}$ and biochemical properties of this animal's digestive glands.

All three halogenated metabolites isolated from $A$. parvula were tested for their antimicrobial potential against marine environmental bacteria, human pathogenic bacteria and pathogenic yeast. 


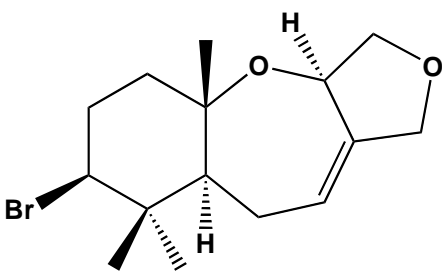

PALISADIN A

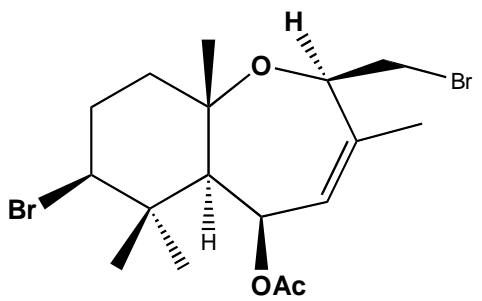

5-ACETOXYPALISADIN B

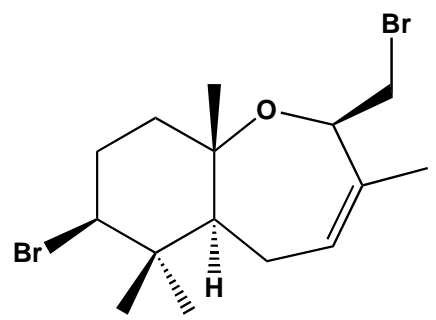

PALISADIN B

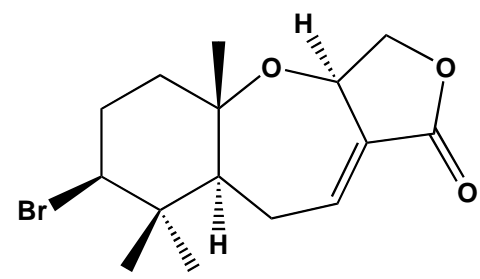

APLYSTATIN

Figure 3. Chemical structure of palisadin A, palisadin B, 5-acetoxypalisadin B and aplystatin isolated from crude methanol extract of Laurencia snackeyi.

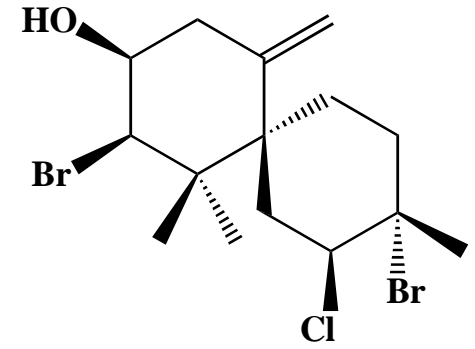

ISO-OBTUSOL

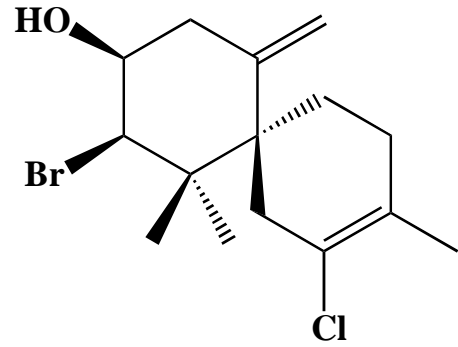

ELATOL

Figure 4. Chemical structure of elatol and isoobtusol isolated from crude methanol extract of Laurencia majuscula.<smiles>CC(=C([NH3+])[NH3+])[C@H]1CC(Cl)=C(C)[C@@](O)(CBr)O1</smiles>

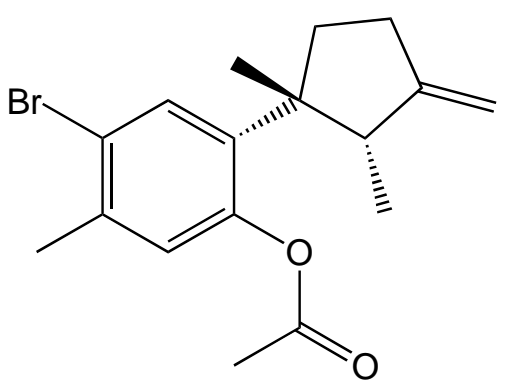

ISOLAURENISOL ACETATE

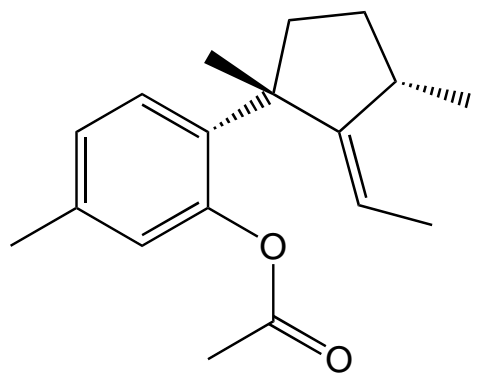

ALLOLAURINTEROL ACETATE

Figure 5. Chemical structure of costatone, isolaurenisol acetate and allolaurinterol acetate isolated from crude methanol extract of Australian Aplysia parvula.

Results are as reported by Vairappan (2003) and Vairappan et al. (2007) [10,11]. Additional cytotoxic test against P-388 cell lines showed apoptosis of the cell lines in 24 hours at concentration as low as 0.05 $\mathrm{mg} / \mathrm{ml}, 0.025 \mathrm{mg} / \mathrm{ml}$ and $0.025 \mathrm{mg} / \mathrm{ml}$ for palisadin A, iso-obtusol and elatol, respectively.

\section{CONCLUSIONS}

Based on our ongoing investigation and previous reports by various researchers, it can be suggested that sea hare from the genus Aplysia have preference for red algae genus Laurencia as its diet, although 
they are also seen grazing on blue green algae. In Sabah waters, A. parvula has shown to prefer the red algae L. snackeyi and L. majuscula. In addition to their ability to sequester and harbor defensive metabolites in its digestive tract, this investigation has also disclosed that $A$. parvula is an oligophagous feeder on the red algal genus Laurencia. The biological activities exhibited by these compounds are very broad and could very well assist this vulnerable soft-bodied organism to defend itself against disease, biofoulers and microbes.

\section{ACKNOWLEDGEMENTS}

The authors would like to acknowledge Dr. Maklarin Lakim of Sabah Parks for granting a research permit to undertake this research. CSV would also like to acknowledge JSPS for the fellowship and assistance that lead to completion of cytotoxic test of the isolated compounds. This study was partially funded by International Foundation of Science (IFS) and Committee for the Prohibition of Chemical Weapons, The Hague, The Netherlands.

\section{REFERENCES}

1. Grkovic, T., Appleton, D.R. and Copp, B.R. (2005). Chemistry and chemical ecology of some common opisthobranch molluscs found on the shores of NE New Zealand. Chemistry in New Zealand, 12-15.

2. Paul, V.J. and Pennings, S.C. (1991). Dietderived chemical defences in the sea hare Stylocheilus longicauda (Quoy et Gaimard, 1824). J. Exp. Mar. Biol. Ecol., 151: 227-243.

3. Rogers, C.N., Steinberg, P.D. and de Nys, R. (1995). Factors associated with oligophagy in two species of sea hares (Mollusca: Anaspidea). J. Exp. Mar. Biol. Ecol., 192: 47-73.

4. Faulkner, D.J. and Ireland, C. (1977). The chemistry of some opisthobranch molluscs. In: Faulkner, D.J. and Fenical, W.H. (eds). Marine Natural Products Chemistry. NATO Conference Series IV. Marine Sciences, Vol. I, Plenum Press, N. Y., 23-34.

5. Penning, S.C. and Paul, V.J. (1993). Sequestration of dietary secondary metabolites by three species of sea hares: location, specificity and dynamics. Mar. Biol., 117: 535-546.

6. Pennings, S.C. (1990). Multiple factors promoting narrow host range in the sea hare, Aplysia californica. Oecologia, 82: 192-200.

7. Higuchi, R., Miyamoto, T. and Ebisawa, Y. (1995). Aplyparvunin, a bioactive acetogenin from the sea hare Aplysia parvula. Tetrahedron Letters, 36: 6073-6074.
8. Wessels, M., König, G.M. and Wright, A.D. (2000). New natural product isolation and comparison of the secondary metabolite content of three distinct samples of the seahare Aplysia dactylomela from Tenerife. J. Nat. Prod., 63: 920-928.

9. Appleton, D.R., Babcock, R.C. and Copp, B.R. (2001). Novel tryptophan-derived dipeptides and bioactive metabolites from the sea hare Aplysia dactylomela. Tetrahedron, 57: 10181-10189.

10. Vairappan, C. S. (2003). Potent antibacterial activity of halogenated metabolites from Malaysian red algae, Laurencia majuscula (Rhodomelaceae, Ceramiales). Biomol. Eng., 20: 255-259.

11. Vairappan, C.S., Anangdan S.P., and Tan, K.L. (2007). Additional halogenated secondary metabolites from the sea hare Aplysia dactlylomela. Malaysian Journal of Science, 26 (1): 57-64.

12. Paul, V.J., and Fenical, W. (1980). Palisadin A, B and related monocyclofarnesols derived sesquiterpeneoids from the red marine alga Laurencia cf. palisada. Tetrahedron Letters, 21: 2787-2790.

13. Miyamoto, T., Ebisawa, Y., \& Higuchi, R. 1995. Aplyparvunin, a bioactive acetogenin from sea hare Aplysia parvula. Tetrahedron Letters, 36(34):6073-6074.

14. Rogers, C.N., Nys, R.D. and Steinberg, P.D. 2003. Ecology of the sea hare Aplysia parvula (Opishobranchia) in New South Wales, Australia. Molluscan Research, 23:185-198.

15. Paul, V.J. and Ginsburg, D.W. (2001). Chemical defenses in the sea hare Aplysia parvula: importance of diet and sequestration of algal secondary metabolites. Mar. Ecol. Prog. Ser., 215: $261-274$ 
Malaysian Journal of Science 28 (3): 269 - 273 (2009) 